\title{
Combined science courses halt declining student interest
}

London. The introduction of combined science courses, replacing the traditional emphasis on the three separate disciplines of physics, chemistry and biology, appears to have stemmed a declining interest in science among British school students, at least in terms of overall numbers.

But the lack of any significant increase in interest in science, particularly when combined with a continued drop in the proportion of students studying science subjects at Advanced (A)-level, is putting pressure on the government to take stronger steps to increase the country's production of trained scientists and engineers.

General Certificate of Secondary Education (GCSE) results published last week show that the number of 16-year-olds taking the traditional subjects is continuing to decline. The biggest drop was in physics, where the number of candidates fell by 16.4 per cent compared to 1992 ; in chemistry and biology, the drop was 13.7 and 12.2 per cent respectively.

In contrast, the number sitting the combined science papers - which count as two separate GCSE passes, and are now, as a result of the introduction of the national curriculum, taken by almost three times as many candidates as those taking single science subjects - increased by 3.7 per cent.

Taking account of the falling number of 16-year-olds in the population, the net result is that the total number of GCSE passes has remained virtually constant. Furthermore, the proportion of candidates achieving the top three grades has increased for those taking both single subjects and the combined science course

The GCSE results have been published a week after those for school students taking A-levels. These revealed a more worrying picture, and in particular a significant drop for the fourth successive year in the number

\section{Backlash threatens biomedicine}

Keele, Staffordshire. Britain's biomedical scientists were warned this week that public disillusionment with the benefits of "hightech" medicine could trigger a backlash against biomedical research.

The warning came from Sir David Weatherall, regius professor of medicine at the University of Oxford, in his presidential address to the British Association for the Advancement of Science, held at the University of Keele.

Weatherall said that the public is becoming less enthusiastic about scientific ap-

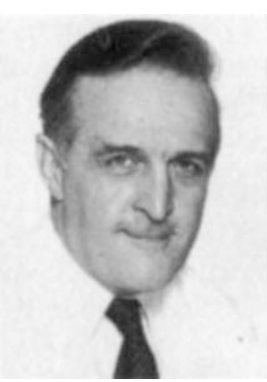

Sir David Weatherall proaches to disease and is turning to alternative approaches. The whole ethos of modern medical practice is being challenged, he said. "While much of this new thinking stems from a genuine wish to improve the quality of patient care in the shortest possible time, there is a danger that it will undermine the role of the basic medical sciences, which have to take a longer-term view of the control of disease."

He singled out genetic engineering as one field in which the public is often misled about the speed with which potential benefits are likely to emerge.

"Claims by molecular biologists that, within the next five to ten years, we will be able to identify the major genes involved and somehow alter our susceptibility to our common killers, are naive and misleading, based as they are on a complete misunderstanding of the enormous complexity of these diseases and those who suffer from them."

Each breakthrough in molecular sciences promises to revolutionize the treatment of a particular disease, but so far has had little impact on our daily lives.

One result has been an enormous increase in the growth of alternative medicine, said Weatherall. Another has been increasing pressure on medical schools to increase their emphasis on communication skills and social science at the expense of basic biological sciences, "It is not surprising, therefore, that our university clinical and basic science research departments are feeling uneasy."

Reaction against the way in which medical practice has evolved in recent years has created a feeling that hightechnology medicine is dehumanizing, and that more attention needs to be paid to preventive medicine. "But because these changes are occurring at a time when society is disillusioned with science, and when support for medical research is so limited, there is a genuine danger that the pendulum may swing too far, and that, in our new customer-driven approach to medical research, the vital role of the basic medical sciences may be neglected."

David Dickson of students taking individual subjects. For example, the number of candidates for physics fell by 9.6 per cent (and for mathematics by 10.6 per cent).

Such figures are not as dramatic as they appear at first sight, as they do not take into account the falling number of 18-year-olds in the population. When this is done, the proportion of this age group taking science A-level has remain roughly constant over the past five years.

Nevertheless one immediate result of the A-level results is to put pressure on the government to introduce new steps to encourage students to follow science rather than arts subjects. Although universities have, with government backing, been increasing the number of science courses on offer, the supply still outstrips demand.

At the end of last week, for example, almost all British universities were still advertising vacant places on courses in physics, chemistry and biology, in contrast to humanities courses, particularly in English and modern languages, from which large numbers of well-qualified applicants have been turned away.

This situation has been encouraging some universities to offer places on conversion courses to students who had been unsuccessful in their bids for places on arts courses. Supporters of these courses claim that they play an important role in promoting a general awareness of science among those planning to enter industry and commerce. But many scientists remain sceptical, claiming that they could become more a way of filling empty lecture halls than of producing creative researchers.

Some organizations claim to see a silver lining in the A-level results. In particular, they suggest that the publicity being given to the large number of vacancies on science courses may encourage some students currently planning to take arts subjects as A-level to switch streams.

"The results are also going to make universities look more closely at how they match the courses they are providing to the changing qualifications of students applying for them", says Cathy Wilson, education officer of the Institute of Physics.

Others, however, warn that the continuing reluctance of students to choose A-levels that will equip them to read science subjects at university reflects a continued devaluation of science by both government and industry, reflected both in the continued lack of employment opportunities for science graduates and their relatively low salaries compared to other professions.

"Even though we are seeing broad support for the changes being introduced at GCSE, the overall figures are not very encouraging, and I worry about the whole climate in which children are not being actively encouraged to pursue careers in science", says David Moore, general secretary of the Association for Science Education. 